\title{
Effects of Heat Transfer through the Walls of a Catholic Church in Semarang Indonesia Simulated with Psi-Therm Software and OTTV
}

\author{
L. M. F. Purwanto ${ }^{1, *}$, Karsten Tichelmann² \\ ${ }^{1}$ Architecture Doctoral Program of Soegijapranata Catholic University, Semarang 50234, Central Java, Indonesia \\ ${ }^{2}$ Department of Architecture, Structural Development \& Building Physics, Technische Universität Darmstadt, Darmstadt 64287, \\ Hessen, Germany
}

Received February 9, 2021; Revised April 2, 2021; Accepted April 22, 2021

\section{Cite This Paper in the following Citation Styles}

(a): [1] L. M. F. Purwanto, Karsten Tichelmann, "Effects of Heat Transfer through the Walls of a Catholic Church in Semarang Indonesia Simulated with Psi-Therm Software and OTTV," Civil Engineering and Architecture, Vol. 9, No. 3, pp. 799-806, 2021. DOI: 10.13189/cea.2021.090321.

(b): L. M. F. Purwanto, Karsten Tichelmann (2021). Effects of Heat Transfer through the Walls of a Catholic Church in Semarang Indonesia Simulated with Psi-Therm Software and OTTV. Civil Engineering and Architecture, 9(3), 799-806. DOI: 10.13189/cea.2021.090321.

Copyright $@ 2021$ by authors, all rights reserved. Authors agree that this article remains permanently open access under the terms of the Creative Commons Attribution License 4.0 International License

\begin{abstract}
Verifying the effects of heat transfer towards the rise of temperature in certain spaces which impact air control and conditioning. Climate change affects the rise of environmental temperatures, with the humid and tropical Indonesia not exempt from its effects. Many church buildings in Semarang, Indonesia, of which were previously partial to natural ventilation, have now opted to rely on Air Conditioning in order to cool their indoor temperatures. As a result, electrical consumption is now at an all-time-high, with the absence of proper adjustments needed to anticipate heat transfer from the outdoors from entering these buildings. Aside from skyrocketing expenses spent on electrical bills, the rise in energy consumption is also partial to uncontrollable energy waste. This research aims to provide a guide in designing the walls of church buildings, in order to reduce massive electrical consumption. Methods used in this research are calculations done through the software Psi-Therm as well as making considerations regarding Overall Thermal Transfer Value (OTTV) in order to provide the big picture of controllable thermal conductivity through church wall design. Research results entail a design model of heat transfer flow obstruction which will be beneficial for future church designs.
\end{abstract}

Keywords Heat Transfer, Psi-Therm, Wall Design, OTTV

\section{Introduction}

Construction developments and renovations of the archdiocese church building in Semarang have shown significant developments as of late. Current considerations related to the development and renovation of the church building, however, are only limited to its architectural design developments, church building expansion, and church rooms additions. Thoughts regarding its building performance' improvements by considering building physics remain subsidiary. The results are the rise of profligate energy consumption, all done for the means of comfort. [1] Data obtained from The Roman Catholic Archdiocese of Semarang reveal a drastic rise in every parish's operational cost due to the use of Air Conditioning in both post-renovated and currently still-in-development church buildings. The effects of world's climate change in regards to environment temperature rise prove discernable in the tropical, humid climate of Indonesia, with the country's high temperature and high humidity levels that last all-year-long. [2] This results in the way Church buildings require thermal comfort in order to allow concentration and focus on transpiring during services. The use of air conditioning is deemed the feasible solution. 
However, changes are still yet to be made when it comes to building design, particularly toward walls that serve as direct borders to the outdoors. [3] The use of air conditioning, if not properly planned out, may result in overindulgence of electrical consumption. [4] The internal impact of this reckless electrical use lies in how operational funding costs are ultimately provided by the collective, due to the lack of subsidy provided by the government. Meanwhile externally, the rise of electrical consumption has become a global issue, one which focus is set on reducing the use of fossil fuel (oil and coal), a resource still prominently used in Indonesia. [2] On the other hand, the most prominent electrical consumption falls under the use of air conditioning within buildings, which make up to about $30 \%-40 \%$ of the total electrical requirements of a structure. [5]

A building's walls serve a significant role as a barrier between the outdoors to the exterior of the building. Façade wall design is determinant to fulfilling the Thermal Performance of a structure. In this research, a software called Psi-Therm - which helped calculate heat transfer along the building walls and thermal bridge which occurred upon the materials chosen for the building construction was used. This software was able to measure and optimize the design in order to obtain a lower heat loss value as well as obviate surface condensation.[6]. In this research, building performance control will be conducted by using Overall Thermal Transfer Value (OTTV) as the means of energy efficiency improvement within a structure [7]. OTTV measures the level of heat collected through a structure's façade [8].

2. Literature Review

Approach used to calculate heat transfer is the Psi-Therm program. This calculation is based on the application of $U_{\text {value }}$ formula on every calculate section of the building, as seen below:[9]

$$
U_{\text {value }}=\left(\frac{1}{\alpha_{d}}+\Sigma \frac{1}{\Lambda}+\frac{1}{\alpha_{l}}\right)^{-1} \quad\left[\mathrm{~W} / \mathrm{m}^{2} \mathrm{~K}\right]
$$

$\alpha_{\mathrm{d}}=$ outdoor surface resistance

$\alpha_{1}=$ indoor surface resistance

$\Lambda=$ total resistance of all materials

Within elements of a building which constitute multiple layers, each layer's resistance is therefore defined as reciprocal. Since thermal conductivity factor significantly defines heat flow in every aspect, surface conductivity value $L$ can be explained mathematically through the equation:[9]

$$
L=\frac{\lambda}{d}
$$

$\mathrm{d}=$ thickness $(\mathrm{m})$

$\lambda=$ conductivity $(\mathrm{W} / \mathrm{mK})$

If temperature differentiation is provided, heat flow can be calculated by simply multiplying conductivity value which is related to temperature difference.

$$
q=L . \delta T
$$

$\mathrm{L}=$ surface conductivity value

$\delta \mathrm{T}=$ Temperature difference

With the assumption that the heat flow is constant, a formula as documented in DIN EN ISO10211: 2008-04 is therefore applied, as seen below:

$$
q=\frac{\left(\theta-\theta_{s}\right)}{R_{S}}
$$

$\mathrm{q}=$ Heat flow

$\theta=$ the inside or outside temperature

$\theta_{\mathrm{s}}=$ the temperature of the interior or exterior surface

$\mathrm{R}_{\mathrm{s}}=$ The interior or exterior heat transfer resistance.

\section{Materials and Methods}

The main object of this research is Yesus Maria Yosef Plamongan Indah Catholic Church, picked specifically because this Church is currently assembling a masterplan to establish an independent parish (see figure 1). Preparations entail reassembling the Church building structure and establishing a masterplan to serve as a guide for future Church developments. This Church building is then documented and its walls calculated by using the Psi-Therm 7 software. Results of this simulation are then followed by the use of OTTV calculation to establish the existing value. Modelling is then done to acquire the most ideal OTTV value, so that the amount of heat that enters the building can be reduced [10].

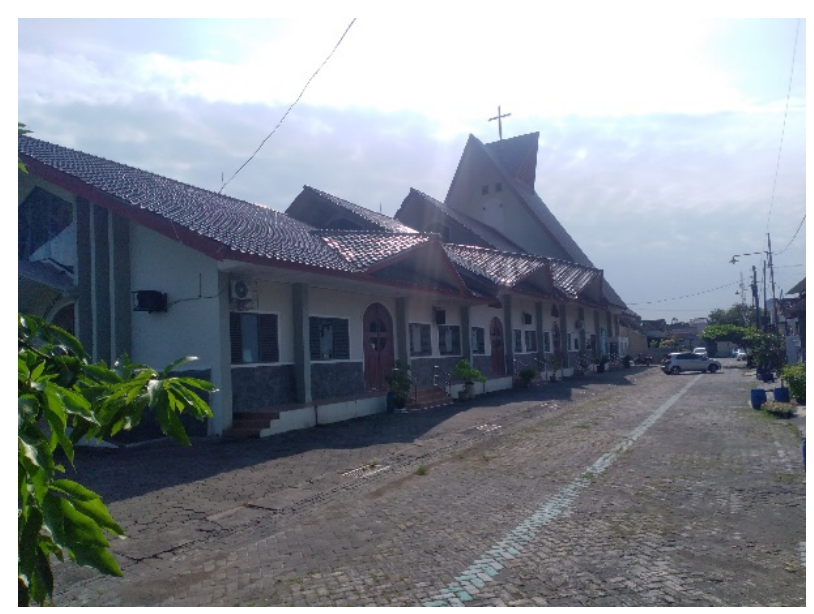

Figure 1. Yesus Maria Yosef Plamongan Indah Catholic Church

\section{Results and Discussion}

Based on temperature measurements done to both inner and outer walls of The Yesus Maria Yosef Plamongan Indah Catholic Church, by using Lutron THM-934S, 2 
channeled- digital thermometers as research objects, the results are as seen in figure 2. These measurements may prove very beneficial for coming up with a design for the structure, since they may help solve energy efficiency issues and improve protection designs, preventing outer-climate conditions from affecting the indoor temperatures.[11]

According to these measurements, the minimum external surface temperature of the east wall is $23,2{ }^{\circ} \mathrm{C}$ at $06.00 \mathrm{am}$, and the maximum external surface temperature is $29,8^{\circ} \mathrm{C}$ which occurs at $12.00 \mathrm{pm}$, while the minimum internal surface temperature of the east wall is $23^{\circ} \mathrm{C}$ at
06.00 am and its maximum internal surface temperature is $28,7^{\circ} \mathrm{C}$ at $1.00 \mathrm{pm}$. As for the west wall, the value of the minimum external surface temperature is $21^{\circ} \mathrm{C}$ at 06.00 am and the maximum external surface temperature is $37^{\circ} \mathrm{C}$ at $3.00 \mathrm{pm}$, while the minimum internal surface is $20,4^{\circ} \mathrm{C}$ at 06.00 am and the maximum internal surface temperature is $35,2^{\circ} \mathrm{C}$ at $5.00 \mathrm{pm}$.

Upon deciding objects of which heat transfer is going to be observed by using the Psi-Therm software, two different surfaces are chosen: windowed and windowless walls, each of which reside on the east and the west sides of the building respectively. (see figure 3).
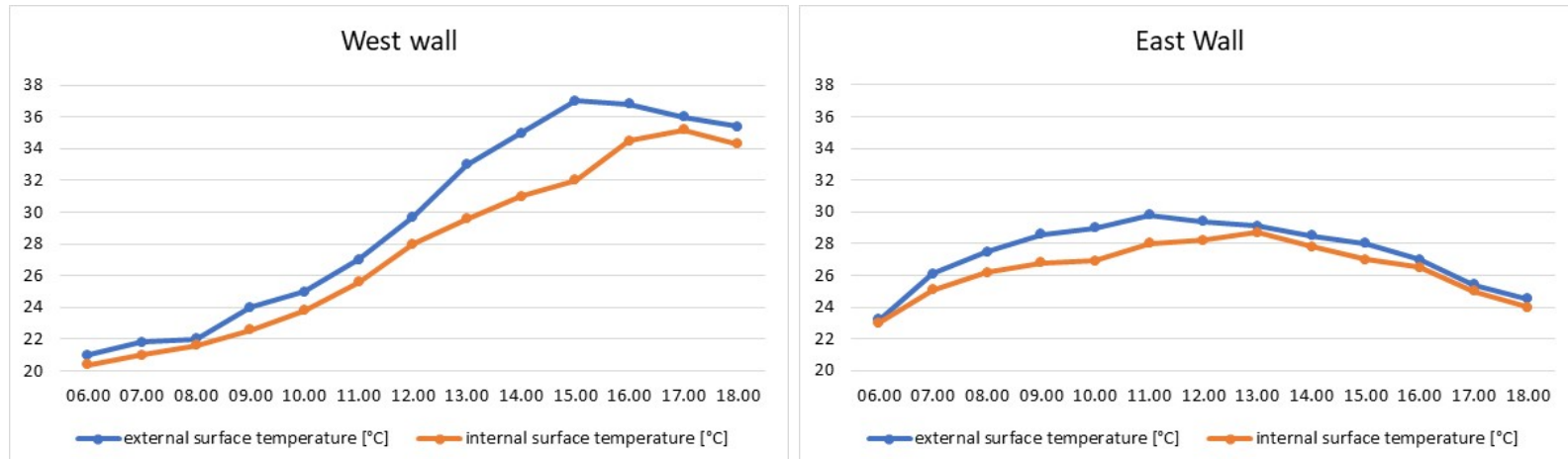

Figure 2. Internal \& external Surface temperature of the East and West walls
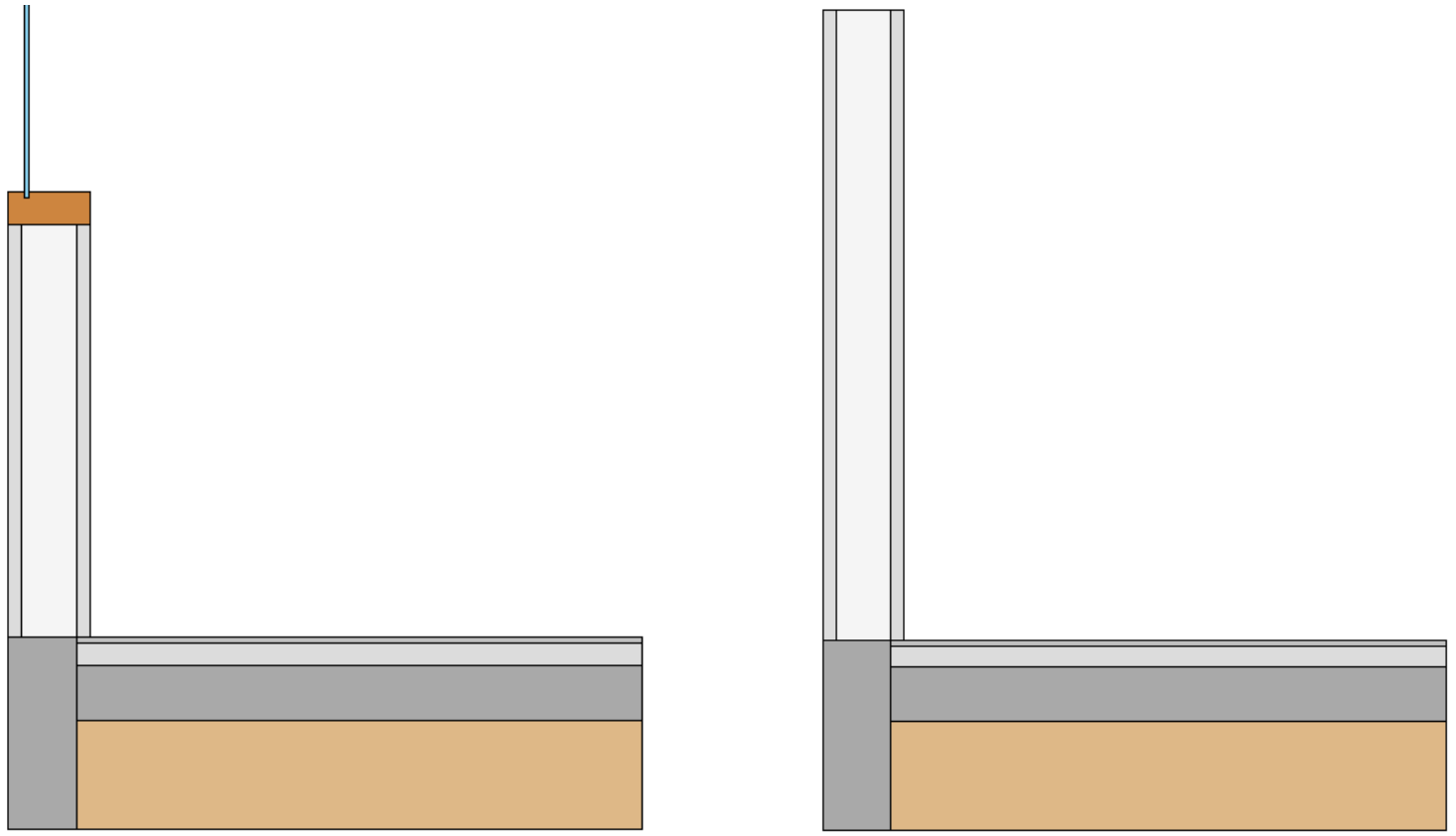

Figure 3. Observation Objects in Detail 


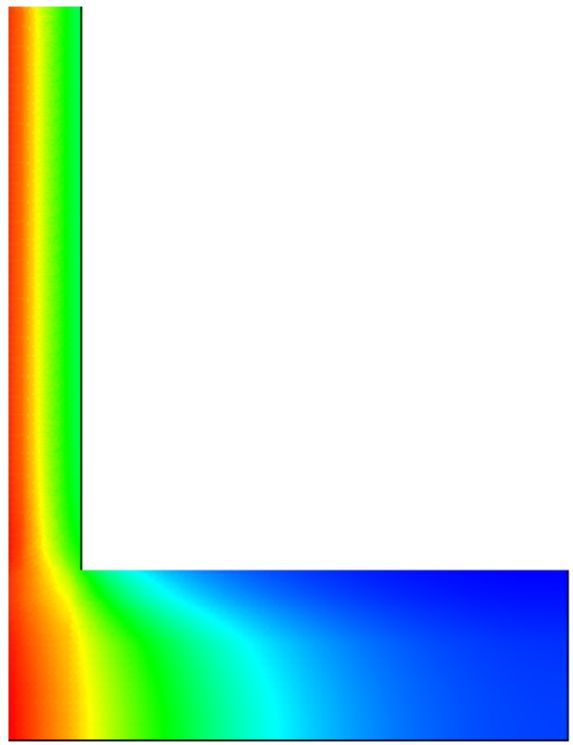

$06.00 \mathrm{am}$

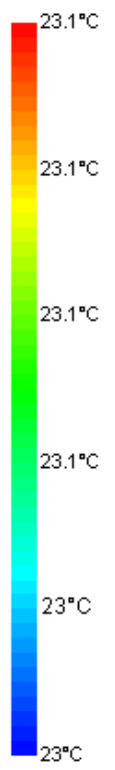

Figure 4. Calculations of the East wall

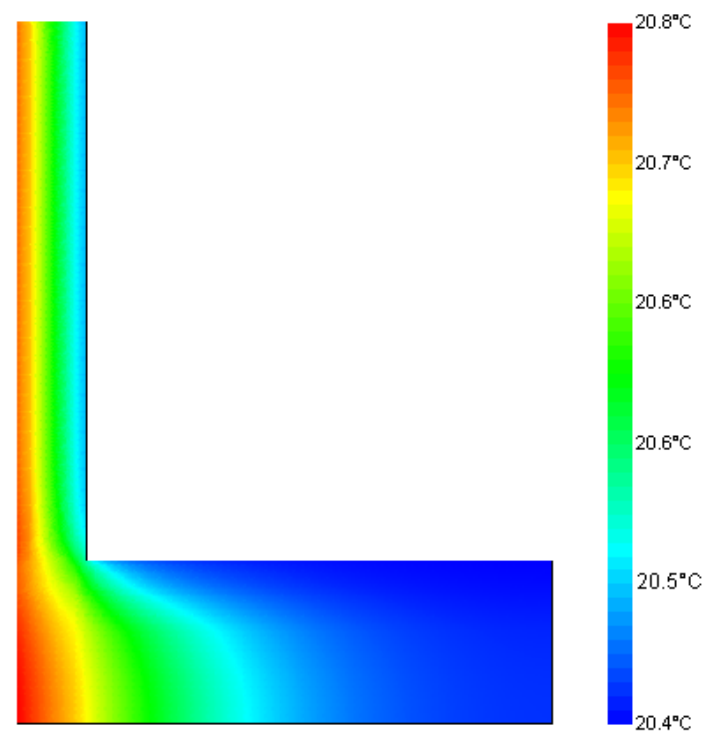

$06.00 \mathrm{am}$

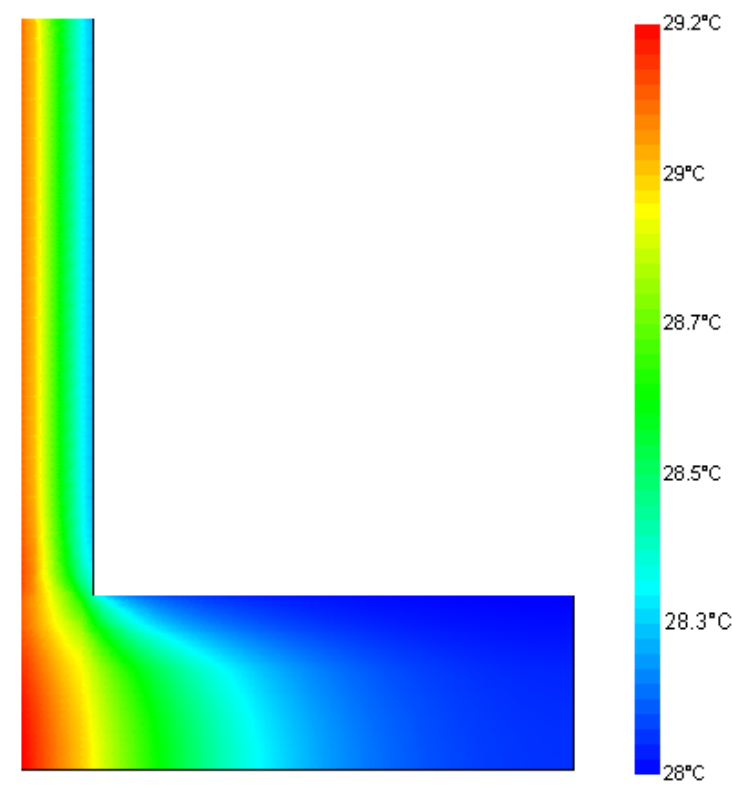

$11.00 \mathrm{am}$

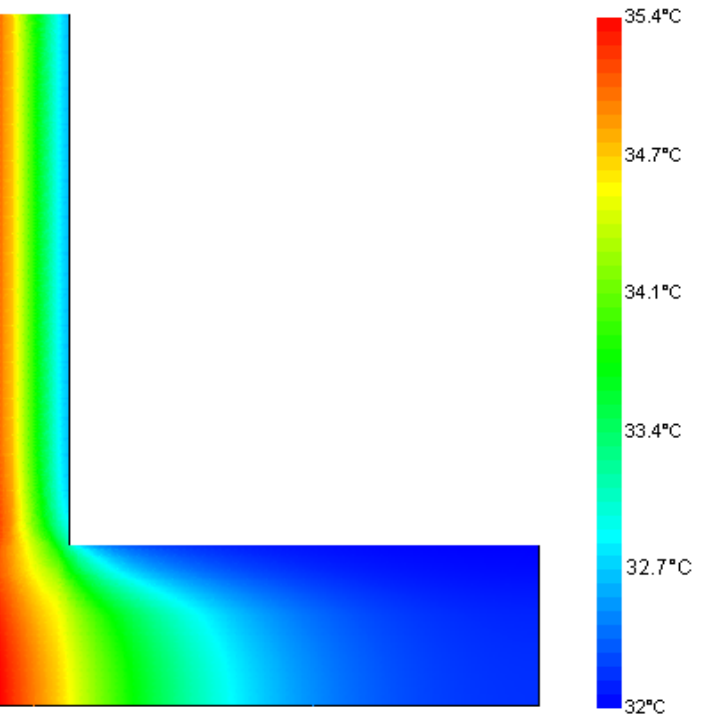

$3.00 \mathrm{pm}$

Figure 5. Calculations of the West wall

Using these two models, calculations are done by inserting each material's Thermal Resistance value in order to obtain a $U_{\text {value }}$. Upon these brick walls, external Surface temperatures on their minimum and maximum degrees are measured, which result in $23,2^{\circ} \mathrm{C}$ at $06.00 \mathrm{am}$ and $29,8^{\circ} \mathrm{C}$ at $11.00 \mathrm{am}$. These data are then inserted to the Psi Therm 7 software to calculate heat transfer and the chances of thermal Bridge occurring.[12] Calculation results are as seen in figure 4 . Calculation results show that at $06.00 \mathrm{am}$, there is not a great difference between heat transfer values that occur on each external and internal surface temperatures, however at $11.00 \mathrm{pm}$ it can be seen that the heat distribution on the external Surface is spread out more evenly and there occurs a heat storage which is then released at its peak at $1.00 \mathrm{pm}$.

Calculations done of the west wall show a heat shift which occurs when the external Surface temperature reaches its peak at $3.00 \mathrm{pm}$, which results in heat being distributed within the structure, consequentially rising the heat level throughout the space (see figure 5). However, since the west side consists of a considerably smaller area compared to the north and the south sides, the impact of heat level rise is not too significant inside the structure.[13] 
On the west side of the wall there is a glass window (see figure 6), heat transfer is significantly dominant upon the glass surface, of which transfers heat expeditiously despite the glass in question being Dark Gray in color, with an $R_{\text {value }}$ of $0,172 \mathrm{~m}^{2} \mathrm{~K} / \mathrm{W}$. Although this is a better choice compared to clear glass which possesses a mere $\mathrm{R}_{\text {value }}$ of $0,169 \mathrm{~m}^{2} \mathrm{~K} / \mathrm{W}$, heat transfer still abundantly occurs upon glass surfaces regardless, therefore shading needs to

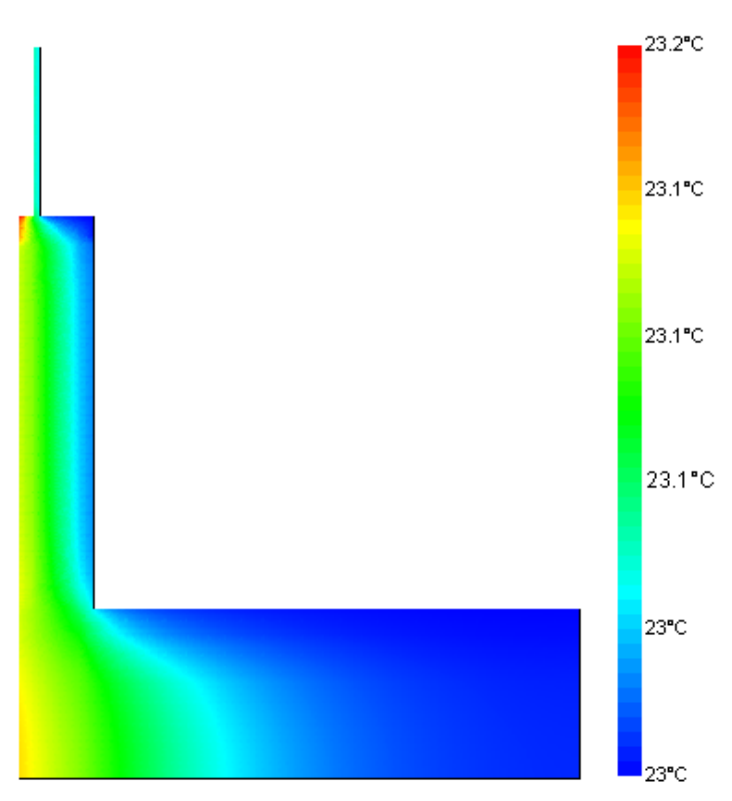

$06.00 \mathrm{am}$ be done on the east side of the building. [14]

On the west side, heat transfer upon the glass surface becomes more dominant (see figure 7). The west side ought to be redesigned to utilize glass windows at its lowest capacity possible. The use of sun shading on the west side often does not guarantee the optimal minimization of heat entering the building. [15]

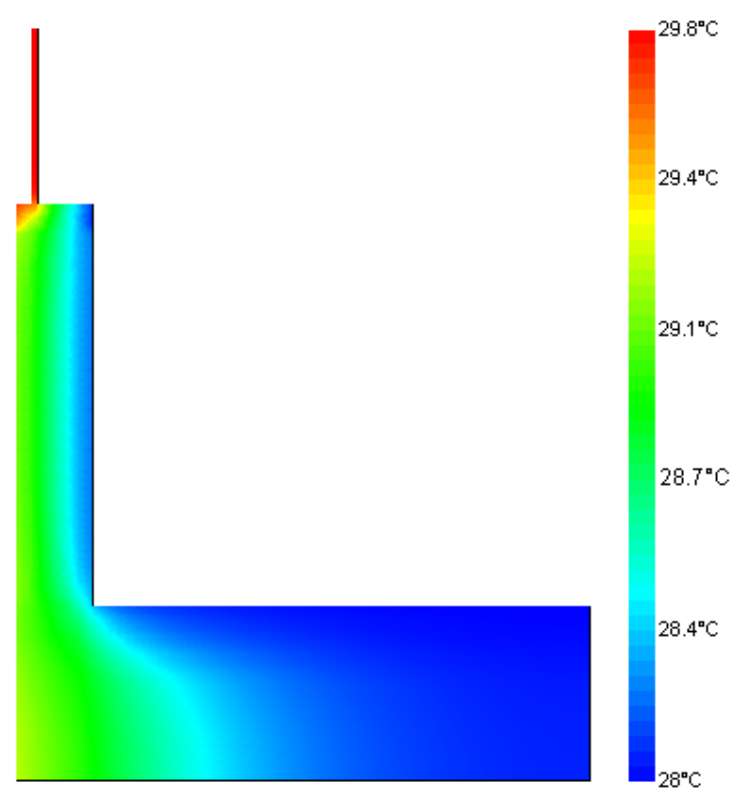

$11.00 \mathrm{am}$

Figure 6. Calculations of the West Side of the wall

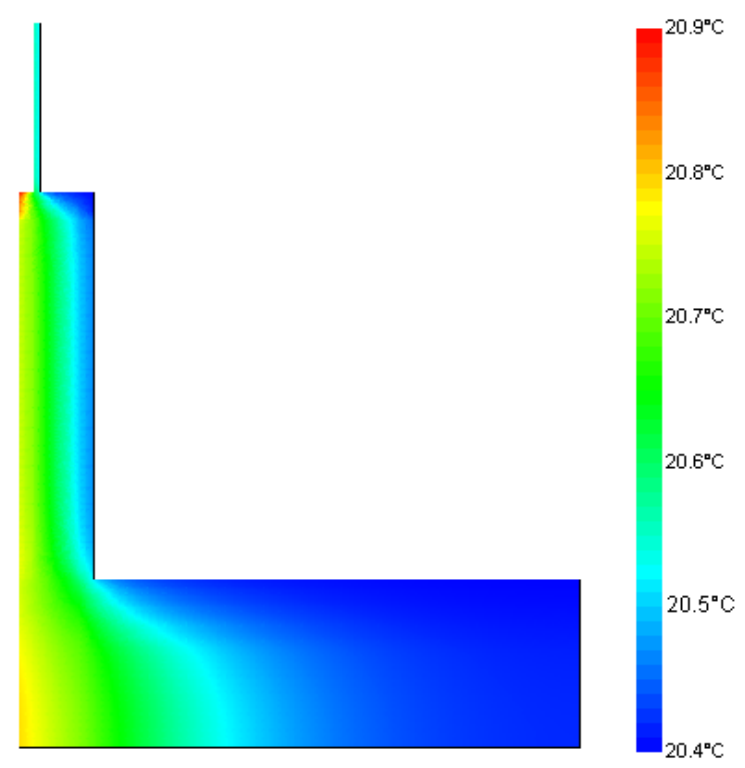

$06.00 \mathrm{am}$

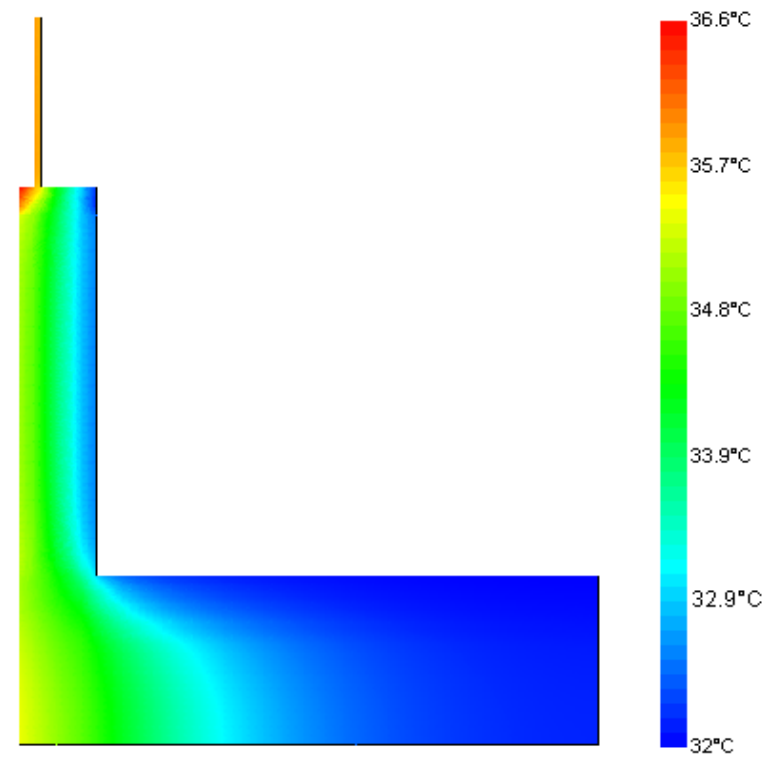

$3.00 \mathrm{pm}$

Figure 7. Calculations of the West wall 
The North and South walls were measured in correlation to the orbit of the sun. In the city of Semarang, which is located along the coordinates $6^{\circ} 58^{\prime} \mathrm{S} 110^{\circ} 25^{\prime} \mathrm{E}$, the sun positioned itself on the South in December and North in June. The sun's angle of incline on both the North and South sides in correlation to the way it hit the walls resulted in small-valued angles of incline, which have already been repelled by the roof, rendering them insignificant in regards to the walls' heat transfer. Thus, the North and South sides of the walls were not taken into account in this research due to their miniscule contribution to the building's heat transfer calculations.

The modelling done on Yesus Maria Yosef Catholic Church building shows that Thermal Bridge does not occur because the door jambs of said building is made out of Bengkirai wood (see fig.3), which possesses the $U_{\text {value }}$ of $2,174 \mathrm{~W} / \mathrm{m}^{2} \mathrm{~K}$, significantly lower than the $U_{\text {value }}$ of brick walls which is $2,850 \mathrm{~W} / \mathrm{m}^{2} \mathrm{~K}$. [17] To add, if Thermal Resistance were to be calculated, both materials amount to the $R_{\text {Wall }}$ value of $=0,180 \mathrm{~m}^{2} \mathrm{~K} / \mathrm{W}$ and $\mathrm{R}_{\text {Frame }}$ value of $=1,09$ $\mathrm{m}^{2} \mathrm{~K} / \mathrm{W}$, which, when summed up using parallel resistance calculation, results in an $\mathrm{R}_{\text {total }}$ of $=0,154 \mathrm{~m}^{2} \mathrm{~K} / \mathrm{W}$, thus declining Thermal Resistance by $27 \%$. The use of a glass window further declines Thermal Resistance of the surface to $43 \%$. Therefore the west wall must come up with a design that minimizes the use of glass windows.[16,18]. Thermal Bridge is a phenomenon which occurs when different materials are used in a single building's façade. In the observed building, the façade was made out of a combination of brick walls and wooden frames. The wooden frame could function as a thermal bridge, however, due to wooden materials' good thermal isolation values in general, the thermal bridge became insignificant.

OTTV calculation done upon these two detailed models of the building above uses the approach as seen below:[11]

$$
\text { OTTV }=\frac{\left(A_{w} \times U \times \Delta T_{s}\right)+\left(A_{g} \times U \times \Delta T\right)+\left(A_{g} \times I \times \theta\right)}{A_{i}}
$$

OTTV $=$ OTTV as per ASHRAE.

$\mathrm{A}_{\mathrm{w}}=$ area of wall + area of glass in $\mathrm{m}^{2}$

$\mathrm{U}=$ Transmittance value in $\mathrm{W} / \mathrm{m}^{2} \mathrm{~K}$

$\Delta \mathrm{T}_{\mathrm{s}}=\mathrm{T}_{\mathrm{s}}-\mathrm{T}_{\mathrm{i}}=\left(\mathrm{T}_{\mathrm{o}}+\mathrm{Ix}\right.$ a/ $\left.\mathrm{f}_{\mathrm{o}}\right)-\mathrm{T}_{\mathrm{i}}$.

To $=$ Outside air temperature in $\mathrm{K}$

$\mathrm{I}=$ radiation intensity in $\mathrm{W} / \mathrm{m}^{2}$.

$\mathrm{a}=$ absorbance of the surface.

$\mathrm{f}_{\mathrm{o}}=$ Surface conductance outside in $\mathrm{W} / \mathrm{m}^{2} \mathrm{~K}$

$\mathrm{T}_{\mathrm{i}}=$ inside air temperature in $\mathrm{K}$

$\mathrm{A}_{\mathrm{g}}=$ Area of glass in $\mathrm{m}^{2}$.

$\Delta \mathrm{T}=$ Difference between internal and external air temperature.

$\theta=$ solar gain factor of window glass.

Calculation results of observed objects are as displayed in table 1,2 and 3 below:

Table 1. Wall and Door Conduction of Yesus Maria Yosef Catholic Church

\begin{tabular}{ccccccc}
\hline Orientation & Construction & Area & $\mathrm{TD}_{\text {eq }}$ & $\mathrm{U}_{\text {value }}$ & $\alpha$ & $\begin{array}{c}\text { Wall \& Door } \\
\text { Conduction }\end{array}$ \\
\hline North & Wall & 176,050 & 10 & 2,850 & 0,30 & 1505,2280 \\
East & Wall & 38,032 & 10 & 2,850 & 0,30 & 325,1736 \\
South & Wall & 176,050 & 10 & 2,850 & 0,30 & 1505,2280 \\
West & Wall & 48,330 & 10 & 2,850 & 0,30 & 413,2215 \\
North & Door & 15,750 & 15 & 2,174 & 0,88 & 451,9746 \\
East & Door & 9,000 & 15 & 2,174 & 0,88 & 258,2712 \\
South & Door & 15,750 & 15 & 2,174 & 0,88 & 451,9746 \\
West & Door & 4,670 & 15 & 2,174 & 0,88 & 134,0141 \\
& & & & & Total & 5045,0850 \\
\hline
\end{tabular}


Calculations done on Wall and Door Conduction show that the North and South sides of the walls hold the highest values due to them being broader in length compared to the East and West sides. The wall and door of the West wall are in direct adjacent to a rice field, however, the door and window are both relatively small in size, resulting in most of sun radiation intensity being blocked by the brick wall. [19] The smaller Wall and Door Conduction values of the west side in comparison to the rest of the walls are beneficial for the OTTV value as a whole.

Table 2. Glass Conduction of Yesus Maria Yosef Catholic Church

\begin{tabular}{cccccc}
\hline Orientation & Construction & Area & $\Delta \mathrm{T}$ & $\mathrm{U}_{\text {value }}$ & $\begin{array}{c}\text { Glass } \\
\text { Conduction }\end{array}$ \\
\hline North & Window & 28,200 & 5 & 5,8 & 817,800 \\
East & Window & 6,968 & 5 & 5,8 & 202,072 \\
South & Window & 28,200 & 5 & 5,8 & 817,800 \\
West & Window & 1,000 & 5 & 5,8 & 29,000 \\
& & & & Total & 1866,672 \\
\hline
\end{tabular}

To determine the $\mathrm{U}_{\text {value }}$ and Shading Coefficient (SC) of the glass, WINDOW 7.7 software- a software developed by Lawrence Berkeley National Laboratory- is used. This software is needed in order to calculate the total window thermal performance indices (i.e. U-values, solar heat gain coefficients, shading coefficients, and visible transmittances. [20]

Table 3. Glass Radiation of Yesus Maria Yosef Catholic Church

\begin{tabular}{cccccc}
\hline Orientation & Construction & Area & SC & SF & $\begin{array}{c}\text { Glass } \\
\text { Radiation }\end{array}$ \\
\hline North & Window & 28,200 & 0,59 & 143 & 2379,234 \\
East & Window & 6,968 & 0,59 & 155 & 637,2236 \\
South & Window & 28,200 & 0,59 & 98 & 1630,524 \\
West & Window & 1,000 & 0,59 & 167 & 98,530 \\
& & & & Total & 4745,512 \\
\hline
\end{tabular}

On the West side of the wall, minimum use of a glass window proves beneficial for the final OTTV result for it is able to decrease the high Glass Radiation value caused by its Solar Factor (SF) multiplier being higher compared to the SFs of the North, East, and South walls. [10] Yesus Maria Yosef Church building's west side consist of mostly walls, hence minimizing the final OTTV value.

OTTV calculations done result in the North wall being $23,43 \mathrm{~W} / \mathrm{m}^{2}$, East wall being $26,33 \mathrm{~W} / \mathrm{m}^{2}$, South wall being $20,35 \mathrm{~W} / \mathrm{m}^{2}$ and West wall being $12,50 \mathrm{~W} / \mathrm{m}^{2}$ in values. The total OTTV value of Yesus Maria Yosef Catholic Church building is $21,272 \mathrm{~W} / \mathrm{m}^{2}$, which is still smaller than Indonesian regulations which require a minimum value of $35 \mathrm{~W} / \mathrm{m}^{2}$. Minimizing OTTV value will result in energy efficiency in the forms of energy cost reduction, improved occupant comfort and improved building operating performance. [21][22]
The results of this research were beneficial for Yesus Maria Yosef Church and may be beneficial for other church buildings in the future as well. Church planning oftentimes merely focuses on spatial layouts and building facades, whilst the discourse on building physics gets ignored, as well as building acoustics; lack of acoustics planning would result in the need to add a sound system, which would typically be costly. Barring natural lighting considerations would also consequently lead to the installation of artificial lighting, which leads to massive energy consumption. Hence, thermal calculations as done in this research should be done, so that outdoor influences (in this case, high air temperatures in tropical climates) would not pose as a thermal burden which impacts energy consumption.

However, in current times, energy efficiency considerations are not yet prioritized. A small church in an archdiocese can spend around Rp 6.000.000,- or 425 US\$ (a hefty value, in comparison to the money collected from the congregation, which amount to Rp 1.500.000,- or 106US\$ per week). Meanwhile, a big church building can spend a budget 3-4 times bigger than a small church does (Data was collected from the Annual Report of the Archdiocese of Semarang). These values are large for Indonesian standards, let alone for the Archdiocese of Semarang, which is situated in a small city. This research was specifically aimed to calculate heat transfer which occurred as well as OTTV calculations to serve as guidance for future church building planning in regards to energy efficiency, along with improving a building's quality. Based on research results, Yesus Maria Yosef Church proved to be an example of a good church building when energy efficiency was taken into account. Moreover, it also showed adequate thermal calculations.

\section{Conclusions}

Yesus Maria Yosef Church building consists of East and West walls surfaces which are smaller in comparison to those of the North and South sides. This serves as a benefit on its own, attenuating efforts in design adjustments if it were to be done to the East and West walls while prohibiting high heat contribution from entering the building. Reduction of OTTV to under 35 $\mathrm{W} / \mathrm{m}^{2}$ must be done especially on the West wall due to its high Solar Factor value. The utilization of glass windows on both West and East sides must be reduced by design in order to minimize heat transfer from the outdoors to the building's interior.

\section{Acknowledgments}

We would like to voice our highest gratitude to Katholischer Akademischer Ausländer-Dienst which has provided financial support for this research. We would also 
like to thank Technische Universität Darmstadt, Fachbereich Architektur, Tragwerksentwicklung \& Bauphysik, all of which have provided support and cooperation throughout this research.

\section{REFERENCES}

[1] A. Aflaki, N. Mahyuddin, and Z. A.-C. M. Awad, "Study on Efficiency of Passive Cooling Strategies on Thermal Comfort Attainment within Tropical Climate,” in Towards Comprehensive and Sustainable Built Environment, 2015, vol. 4, no. November, pp. 133-143.

[2] T. Randazzo, E. De Cian, and M. N. Mistry, "Air conditioning and electricity expenditure : The role of climate in temperate countries $\hat{\sim}$," Econ. Model., vol. 90, no. June 2019, pp. 273-287, 2020, doi:10.1016/j.econmod.2020.05.0 01.

[3] J. Vijayalaxmi, “Concept of Overall Thermal Transfer Value (OTTV) in Design of Building Envelope to Achieve Energy Efficiency,” Int. J. Therm. Environ. Eng., vol. 1, no. 2, pp. 75-80, 2010, doi: 10.5383/ijtee.01.02.003.

[4] D. F. Dominković et al., "Potential of district cooling in hot and humid climates,” Appl. Energy, vol. 208, no. May, pp. 49-61, 2017, doi: 10.1016/j.apenergy.2017.09.052.

[5] S. Birkha, M. Ali, M. Hasanuzzaman, N. A. Rahim, M. A. A. Mamun, and U. H. Obaidellah, "Analysis of energy consumption and potential energy savings of an institutional building in Malaysia,” Alexandria Eng. J., vol. 59, no. 6, pp. 1-16, 2020, doi: 10.1016/j.aej.2020.10.010.

[6] 2020, Overview Psi-Therm, https://www.psitherm.uk/03/27/ 2020 09:58

[7] A. L. S. Chan and T. T. Chow, "Calculation of overall thermal transfer value (OTTV) for commercial, ade in buildings constructed with naturally ventilated double skin fac subtropical Hong Kong,” Energy Build., vol. 69, no. February, pp. 14-21, 2014, doi: 10.1016/j.enbuild.2013.09.0 49.

[8] S. C. M. Hui, "Overall Thermal Transfer Value (OTTV): How to Improve Its Control in Hong Kong," in One-day Symposium on Building, Energy and Environment, 2014, no. June, pp. 1-11.

[9] T. Schoch, Psi-Therm Manual, 1st ed. Latendorf: Visionworld GmbH, 2019.

[10] F. W. H. Ã. Yik and K. S. Y. Wan, “An evaluation of the appropriateness of using overall thermal transfer value (OTTV) to regulate envelope energy performance of air-conditioned buildings,” Energy 30, vol. 30, no. 2, pp. 4171, 2005, doi: 10.1016/j.energy.2004.03.001.

[11] R. Slavik and M. Cekon, "Study of Surface Temperature Monitoring in the Field of Building," Procedia Eng., vol. 161, pp. 1135-1143, 2016, doi: 10.1016/j.proeng.2016.08.526.

[12] S. M. Sajjadian, "Risk Identification in the Early Design Stage Using Thermal Simulations-A Case Study,” Sustain., vol. 10, no. 1, 2018, doi: 10.3390/su10010262.

[13] S. A. Algarni, "Modeling Radiation Heat Transfer for Building's Cooling and Heating Loads: Considering the Role of Clear, Cloudy, and Dusty Conditions in Hot and Dry Climates,” 2015.

[14] K. M. Al-Obaidi, M. Ismail, and A. M. Abdul Rahman, "Passive cooling techniques through reflective and radiative roofs in tropical houses in Southeast Asia: A literature review," Front. Archit. Res., vol. 3, no. 3, pp. 283-297, 2014, doi: 10.1016/j.foar.2014.06.002.

[15] V. Chetan, K. Nagaraj, P. S. Kulkarni, S. K. Modi, and U. N. Kempaiah, "Review of Passive Cooling Methods for Buildings,” J. Phys. Conf. Ser., vol. 1473, no. 1, 2020, doi: 10.1088/1742-6596/1473/1/012054.

[16] I. Sarbu and A. Dorca, "Review on heat transfer analysis in thermal energy storage using latent heat storage systems and phase change materials,” Int. J. Energy Res., vol. 43, no. 1, pp. 29-64, 2019, doi: 10.1002/er.4196.

[17] 2009 ASHRAE Handbook-Fundamentals chapter 6

[18] R. Hasanuzzaman, M. Hasan, and H. Masjuki, "Overall Thermal Transfer Value of Residential Buildingsin Malaysia,” J. Appl. Sci., vol. 9, no. 11, pp. 2130-2136, 2009.

[19] R. Ponechal and D. Staffenova, "Impact of external wall insulation thickness on internal surface temperature behaviour," in MATEC Web of Conferences XXVI, Theoretical Foundation of Civil Engineering, 2017, vol. 00140, pp. 1-6.

[20] "WINDOW, A computer program for calculating total window thermal performance indices." https://windows.lbl. gov/software/window.

[21] A. K. Aliyu, A. L. Bukar, J. G. Ringim, and A. Musa, “An Approach to Energy Saving and Cost of Energy Reduction Using an Improved Efficient Technology,” Open J. Energy Effic., vol. 4, no. December, pp. 61-68, 2015.

[22] W. Feng et al., "A review of net zero energy buildings in hot and humid climates: Experience learned from 34 case study buildings,” Renew. Sustain. Energy Rev., vol. 114, p. 109303, 2019, doi: 10.1016/j.rser.2019.109303. 